\title{
Analysis of the Open University of Brazil Program as a National Policy for Public Distance Education in Brazil
}

\author{
Eucidio Pimenta Arruda \\ Correspondence: Eucidio Pimenta Arruda, School of Education, Federal University of Minas Gerais, Belo Horizonte, \\ Brazil.
}

Received: August 4, 2020

doi:10.11114/jets.v9i5.4958

\author{
Accepted: May 20, 2021 \\ Online Published: May 24, 2021 \\ URL: https://doi.org/10.11114/jets.v9i5.4958
}

\begin{abstract}
This paper aims to understand how free distance education policies in Brazil, the Open University of Brazil (OUB) System, and public relations between this program and the weakening of distance education in Brazilian public education. Discuss the relationships between DE and teacher training in Brazil, as well as the program's weaknesses in directing teaching, and engage in dialogue with DE resistances in other areas of training in Brazilian public universities. We point out the ineffectiveness of expanding vacancies to train teachers and the perspective of planning the use of distance education in public universities, or what leads to the growing resistance to this model of education within institutions. Finally, that to strengthen distance education in Brazilian public education, and it is necessary to set aside programs of unstable duration, such as the OUB, and to think about public policies that affect the regularity and breadth of training areas in distance education.
\end{abstract}

Keywords: teacher training, open university of brazil program, distance education in brazil, higher education

\section{Introduction}

Distance education $(\mathrm{EaD})$ has been used in Brazil since the beginning of the 20th century, but higher distance courses were only approved in 1996, based on the Law of Guidelines and Bases of Brazilian education.

In 1998, we have the first law to regularize Distance Education (DE) in higher education in Brazil. According to Formiga (2009), was very important to increase distance education, because of the potential democratization of access to school at all levels, especially in countries of continental dimensions, such as Brazil.

In this line of argument, it should be noted that the discourse of democratization is the primary driver of Brazilian public distance education, due to the government's inability to promote an intense expansion of public higher education in face-to-face mode. Although in the last 15 years the number of university students has doubled, about $80 \%$ of the new vacancies occurred in the private sector of higher education (Inep, 2020).

The first Brazilian public initiatives in Distance Education occurred in government projects, such as the Veredas Project, in the state of Minas Gerais (2002), the Cederj Consortium (2000), in the state of Rio de Janeiro, and the Federal University of Mato Grosso (UFMT), the latter considered a pioneer in the implementation of distance learning in public universities, through the creation of the Pedagogy course in the late 1990s.

It is from 2006 that Brazil began a major transformation in public policies in distance education by promoting the creation and consolidation of a national distance education program, called Open University of Brazil (OUB), through Decree No. 5800 of 2006 (Brazil, 2006).

The OUB system works as a partnership program between the Coordination for the Improvement of Higher Education Personnel (CAPES), Brazilian states, and municipalities, from places of study in person. The objective is to increase the number of students in teacher training courses in the inland of Brazil.

Despite being the largest public distance education program in Brazil (Arruda, 2015), which contributed a lot to the sport in the country, on the other hand, it is also responsible for the weakening of DE within public universities and the lacunae legislation that hindered the growth of education. DE in other areas of knowledge, such as Law, Engineering, and Health.

Consolidating a national distance education policy involves all areas of knowledge and not just teacher training. In Brazil, distance education policies developed by different governments were directed only at this area, making it 
difficult to present proposals that contemplate other fields of knowledge.

This article aims to discuss the development of public DE through the OUB system, discuss how teacher education has become the most offered option in Brazilian DE, both private and public. It seeks to analyze the paths taken by the public, pointing out its challenges, limits, and possibilities. It also indicates possible ways for public DE to stop being recognized as part of government programs and can be built as a state policy, in a perspective of inseparability between teaching, research, and extension, typical of university education.

\section{Dimensions of teacher education as an argument for the constitution of the Open University of Brazil System in public higher education institutions}

University distance education in public institutions, as a national policy, began with the OUB system in 2006, through decree 5800. As before stated, there were specific and localized projects, either by governmental or institutional initiatives, among which we highlight the Veredas Project (2002-2005) in Minas Gerais, the Cederj Consortium (2000) in Rio de Janeiro (which still operates under OUB funding), and the Federal University of Mato Grosso (UFMT), which launched a Pedagogy course in the late '90s in collaboration with Decree No. 5800 was issued in 2006 and was implemented in 2007 through the Business Administration course (AUTHOR and AUTHOR, 2015). The OUB system is a consortium involving state municipalities (which offer the presence support poles), public higher education institutions (federal, municipal, and state) that provide the courses and is regulated and funded by the Coordination of Personnel Improvement (CAPES).

As a public policy, the OUB system is constituted as a government program, although it has survived various administrations. The plan was created to meet a specific and localized teacher education. Since its start, it has always had a focus on teaching at public primary schools. The principal argument is the need to train more teachers to meet the goals of the National Education Plans (Brazil, 2014), which is to increase the number of teachers with higher education and the number of teachers who teach in the area of their formation.

It is interesting to realize that what drives the emergence of the program-the training of teachers is also what can guarantee the longevity we already have. The OUB system has completed ten years of activity and, if the current state of teacher education for primary school, the program still has relative strength to continue to function in the coming years. Census data from primary schools showed that the number of teachers trained in tertiary education, as well as teachers trained in the area where it underwent little change.

The percentage of teachers in primary school with a higher education degree, for example, increased from $69 \%$ to $74.4 \%$ between 2013 and 2017. The rate of elementary and high school teachers who have higher education compatible with the area of knowledge in which they teach ranges from $40 \%$ to $46.9 \%$ and from $49 \%$ to $54.9 \%$, according to the Census of Basic Education data analyzed between 2013 and 2017.

The data collected allows us to question the effectiveness of the OUB system in its main policy, which is teacher training. According to Ferreira and Clímaco (2015) between 2006 and 2014, 20 thousand teachers had been trained at the undergraduate level and another 70 thousand at the level of specialization, in a universe of 600 thousand open positions, or a success rate of only $15 \%$.

It is possible to ask pertinent questions: Is investing significant public resources in teacher training the best policy for improving Brazilian primary education? Or should we include dimensions such as working conditions, wages, valuation, and other elements that imply the place that teaching occupies in Brazilian society?

This issue is essential, especially when we analyze other data on distance education in Brazil. Private institutions have promoted, in the last ten years, a process of resizing teaching modality in the vacancies offered in the degree. In 2007 , there was $25 \%$ of the enrollment of private institutions in the degree, and, in 2016 , this number jumped to $60 \%$ of the total enrollment.

Thus, it appears that distance learning, rather than a formative need to meet Brazilian educational demands, is perceived as a business model in which higher education courses are offered with significant cost reduction and minimal resistance by councils or class associations.

The main argument used to expand only the area of teacher training is the lack of these professionals in Brazilian public schools and the need to train a large number of teachers in the short term.

Despite appearing a solid argument, since, according to data from the Brazilian government of 2019, about 300 thousand teachers with adequate training in Brazil are lacking, it is confronted by the fact that 150 thousand new teachers are trained every year, according to data from the same Census.

There are not much precise data on what teachers are trained to do after graduation, but it can be inferred that the argument for building specific distance learning programs to train more teachers is not supported, as we will see below. 
Mill (2016) highlights that the OUB system represents a qualitative and quantitative improvement for public distance education, mainly because it has integrated Brazilian public universities. But the same author states that there is precariousness in the offer of courses, which is supported by the little management and pedagogical experience of teams in public universities.

On the one hand, the continuity of programs such as OUB can affirm that the Brazilian government sees distance education as a strategic training model; but, the continuation as a program and not as a state policy tends to tell us that there is no political interest in the regulation of DE as a public distance education policy in Brazil.

Although there are figures that point to the need to train more teachers, there are important elements to understand these absences. In Brazil, salaries are low, according to official data (PNAD, 2020), a teacher earns half the salary of any other professional with a college degree. There is overcrowding in classrooms, unattractive career plans, poor physical structure in schools, among countless other challenges faced by teachers.

Pinto (2014) states that the number of students seeking teacher training courses has increased in Brazil. Data from OECD (2019) show that the percentage of students who choose teacher training courses in Brazil is four times higher than the OECD average, reaching almost $20 \%$ of enrollments in Brazilian higher education.

This high enrollment rate is mainly due to the low cost of teacher training courses. Data from the Brazilian educational census (2018) show that the amount paid by students to take these courses is among the lowest compared to other areas.

Due to such costs, we have in the country about 1.6 million vacancies offered in teacher training, but no more than 300 thousand interested people and about 150 thousand trained annually.

The demand for teachers is around 2.3 million vacancies for teachers in all areas, according to data from the 2019 School Census. Pinto (2014) demonstrated in an extensive study of data from INEP and the School Census between 1990-2010, that, except for the areas of physics, science, and foreign language, in all other areas there was already a level of teachers adequate to the number of vacancies needed.

It is necessary to highlight the need for new research that also shows the migratory flows of undergraduates, as well as the relationship between demand and the number of personnel trained by region, since the national average data may present inconsistencies that help us in the analysis of the object. Brazil is a country of continental dimensions and has great economic diversity, causing an excess of teachers in one region and a shortage in another.

The analysis of public education policies leads to the perception that there is relative strength in the argument that emergency and rapid solutions solve the problem of teacher shortages in Brazil - which strengthens EAD as a possible "solution" to the problem presented. On the other hand, the concrete data weaken the need to expand distance education, since they show that there are enough trained teachers. This causes public policies to be misdirected and a high percentage of public resources to be spent on training thousands of distance teachers through OUB, while there is little interest from people trained in working in the area.

The educational policy of teacher training has a political character to demonstrate the government's concern with the teaching crisis, which is not supported by the development of studies and analyzes that aim to better understand the phenomenon of teacher shortages in Brazil.

The proposal to expand the offer of teaching vacancies through distance education in public universities is politically successful, as it appears to be concerned with Brazilian education. On the other hand, it does not find support in official data and fails to deal with deeper problems such as wages and working conditions.

In addition, by promoting only the training of distance teachers, an idea is created that the most fragile area, with the least social and economic value, is the one chosen to be offered at a distance. Therefore, an interpretation is constructed that only low-value courses are offered at a distance and, therefore, turn to mass training and of low quality.

In Brazil, more than $60 \%$ of vacancies in higher education courses, including from private universities, are aimed at teacher training. As stated earlier, these are cheaper courses with better financial returns for institutions.

The relative excess of offers causes a certain prejudice about the formation of teachers. An idea is built that they have worse quality than the others since there are not many offers at a distance from other professional areas.

Despite the data directed to the understanding that there is no lack of vacancies for teacher training in Brazil, the only national public distance education program in Brazil, the OUB system, maintains a priority policy only for teacher training.

Oliveira (2018) found that most of the research conducted on OUB deals with pedagogical practices, teaching, or tutoring. There is a lack of analysis or discussion that leads to an expansion of distance education as a promoter of general vocational training and not a particular professional field. The discourse that the lack of teachers justifies the 
expansion of teaching vacancies in distance education strengthens the idea that DE is unique to this category, which can weaken DE and teaching. Such reading may incur teacher devaluation recruitment in society (Kallajian and Aquino (2017).

That is, implementing a policy aimed at addressing a teacher shortage in public schools, or investing in expanding teacher training places in higher education, may be linked to a strategy of significantly increasing the number of teachers trained above the minimum, so that qualified professionals can fill positions that are being abandoned by active documents.

The difficulty, not only in the federal government through CAPES, but also in the public institutions participating in the OUB system, redirects or talks about how consolidated distance education, helping to create a path that meets only one professional category, historically fragmented in all respects or it could perform a gap reading in distance education as if it were accepted in fragile areas of knowledge. There is an objective lack of programs aimed at expanding distance education through the provision of other deficit fronts in higher education in Brazil.

Therefore, it found an environment in public higher education institutions, in which it is necessary to maintain an EaD as a marginal modality, with all configurations and problems, as presented in the next topic.

From an educational policy perspective, the Brazilian government's enterprise in recent years weakened distance education and the OUB system by defining very different parameters of face-to-face learning in long-time action, compared to other past distance education programs.

That this double movement: lack of actions outside teacher education and maintaining distance education as a program through OUB helps to strengthen resistance to distance education in IPES and weaken its functioning, resulting in almost the impossibility of regular broad offerings, by the autonomy and policy of public institutions.

\section{Contributions of emergency programs to the weakening of distance education in federal public institutions}

The data obtained for the development of this work comes from the author's experience as a participant in the OUB system over the last ten years and by analyzing data collected from the OUB coordinator's forums during this period. It is necessary to inform you that such data can not constitute any identification of persons or IPES, but only the treatment of quantitative and qualitative data obtained in the innumerable interactions performed during these years.

One of the first problems detected in the consolidation of distance education with IPES concerns a slow and fragile process of institutional recognition of the modality as a regular action of the institutions participating in the OUB system. In 2010, a working group on the institutionalization of distance education was set up, set up under the responsibility of the forum of coordinators of the Open University of Brazil system, and supported by CAPES. This forum was discontinued in 2012, mainly because it was unsuccessful in building a political perspective on institutionalization.

In 2017 there was a new constitution of the working group (WG) on the institutionalization of distance education in public institutions of higher education. The first work was based on the application of a questionnaire to get answers about the working conditions of DE in universities.

The data from the WG, although preliminary, seeks to perform statistical surveys on the implementation of DE in institutions that are part of the OUB system and, thus, focus more on the system itself than on the dimension of institutionalization, which should be considered unrelated to the OUB.

It is considered that more than $70 \%$ of the researched institutions are unable to offer distance education without specific financial support, that is, there is no financial regularity to offer DE. This demonstrates a relatively high dependence on specific programs for the modality and reinforces the arguments presented in this text.

From a conceptual point of view, it is observed that distance education is understood in Brazilian public institutions as a modality to be developed by a specific management unit, outside the classroom school. In practice, it is as if distance education is another institution within the traditional university institution.

This denomination is responsible for directing the understanding that Distance Education develops marginally, separately, from other educational initiatives of public institutions. Despite this, there are no elements in the Brazilian legislation that constitute such a distinction, since the control, supply, and evaluation mechanisms are identical for face-to-face and distance education.

The data in this document, when analyzed together, lead to a distance education offered that only exists when resources are directed by the federal government and, given the nature of instability and financial exceptionality, the DE units of public institutions make "external objects" to the university itself.

This creates an atypical situation in which colleges and academic units no longer have the autonomy to decide when to 
offer distance learning courses and become dependent on specific DE units that will say when there will be money to offer a particular course. This resizes university autonomy, which, in Brazil, allows universities certain freedom to decide their strategies for serving the population.

The concept of free distance education not linked to face-to-face education enhances the following problems of institutionalization of the modality in public universities:

(a) Distance education actions are still restricted to sectors, usually under the responsibility of an OUB system coordinator. This means that EAD initiatives do not exceed the induction made by the Brazilian government.

(b) Distance learning is deficient in terms of possibilities for immersion in research and extension.

(c) The lack of mobility of intermodal students, that is, the opportunity for students to migrate between on-site and distance courses, or to achieve curricular achievement through the completion of subjects in a different modality than the one they are enrolled in.

(d) Weakness in the internal regulations of the universities, such as academic standards, recognition of the charges of professors, institutional recognition of distance courses, and equivalence of participation in daily decision-making.

From the data obtained and the documentation elaborated in the scope of the OUB, it is possible to infer that there are movements of institutionalization construction of singular DE concerning face-to-face education, in the sense of the development of qualitative and qualitative parameters. It is a political position, in which distinguishing between modalities would serve to strengthen distance education as a specific modality.

This perspective can be glimpsed when, for example, norms are built inside that differentiate students from the presential and distance modalities, or if they question parameters that distance the teaching work performed in both patterns (Mill, 2016).

Distance education can be distinguished from a methodological, didactic, and technological standpoint because it presents singularities in the field of face-to-face learning. The difficulty we find in the proposed peculiarities is that it seeks to construct parameters so different that they characterize distance education as a marginal modality since it needs to have most of the distinct paths.

The sectorization of distance education provision is one such example of singularization that weakens the modality. Firstly, it strengthens the separation between face-to-face distances, as it assumes that patterns need to be discussed and constructed separately. It reconfigures the historically established institutional structures, which are guided by the autonomy and democratization of pedagogical choices and propositions. In general, the sectorization of DE within government programs such as the OUB system creates a reliance on external induction and, as financial resource times are distinct (and much faster) from academic times, the risk of institutional and institutional mishaps occurring centralizing decisions about which courses to open or not is significantly high.

From university education, the perspective presented to the student of an IPES consists mainly of teaching experience, since financial incentives, such as specific grants for research and extension, are non-existent as the public policy of the Brazilian funding agencies. Institutions that promote research and extension to distance learning students generally do so through financial strangulation of resources previously linked to face-to-face courses, given the lack of this resource for distance learning.

2016 Higher Education Census data shows that the average age of the incoming student is approximately 30 years, ten years older than the face-to-face students. The average age of graduating students is 35 years old, precisely ten years older than students of the other type. Distance education students have different specificities, such as: being married with children, being mostly in the job market, having a lower family income. The permanence of the student of distance education is, therefore, a great challenge, since all the data demonstrates that the obstacles to continuing studies are high.

It turns out that there are no public policies to keep students enrolled in public institutions-in fact, there is the opposite-a ban on the use of financial resources to support the students of distance education. Because the National Student Assistance Program (PNAES) does not allow funds to be directed to students of DE, as can be observed in Decree No. 7.234, of July 19, 2010.

The asymmetry found in the treatment of distance education compared to face-to-face learning is likely to have important implications for the quality of training (which is lacking in research and extension), success, and failure rates (such as dropout rates, permanence, and linked quality score results obtained in disciplinary assessments).

The asymmetry found in the treatment of distance education in comparison with face-to-face learning is likely to have important negative implications for the quality of training. Distance learning courses only emphasize teaching - there are no formal and regular scientific training initiatives, in research and university extension. 
If we consider the Brazilian official evaluation mechanisms, we can infer that the quality of education is at least the same. From data collected in the system of registration of higher education institutions and courses (E-Mec) between December 2017 and January 2018 (available at http://emec.mec.gov.br), we realized that the courses Distance learning courses offered by public institutions evaluated by INEP have the same grade or higher than the face-to-face classes. The INEP assessment considers not only student performance but also other factors such as infrastructure and faculty. Thus, the data obtained to cover the provisional course concepts (CPC) and the Course Concept (CC). Different courses were analyzed, such as a degree in Pedagogy, Mathematics, Chemistry, Bachelor of Business Administration, Geography, Engineering, and others. In all of them, the modalities are compatible in terms of grades obtained in the evaluations.

Although the data seem to be positive for those who defend the modality of distance education, they end up reinforcing the fragility of the pattern in public institutions, as it takes little account of the consolidation of the modality from an institutional point of view and the evaluation strategies.

Infrastructure assessments, as well as staff appraisals, most often deal with existing conditions geared towards meeting face-to-face education. For example, existing laboratories, when evaluated by INEP staff, are already present in the institution to attend classroom education but are considered in the evaluation of distance learning courses. The misconception can be understood to the extent that laboratory-based face-to-face activities necessarily occur at the face-to-face support poles. Decree No. 9054 of 2017 (Brazil, 2017) can change this situation, as it enhances the use of the headquarters structure for the provision of distance learning courses, but it can also improve the regionalization of the distance learning offer, as it makes the host institution responsible for all face-to-face support poles in a context in which municipalities and states are, through a cooperation agreement with CAPES, the direct financial officers and the budget matrix of public universities do not include investment and spending on structures operated by bodies other than their institutions.

Staff appraisal can encounter similar problems since INEP instruments consider the active teachers of the institution to be responsible for offering the course and also for monitoring and evaluating the pedagogical propositions of the course.

It happens that in most courses offered under the OUB system, teachers are not sufficient, but provisional, in a situation of ephemerality in the class, since it develops pedagogical activities strictly linked to the payment of teacher training scholarships (according to CAPES Ordinance No. 187 of 2016). That is, the teacher's situation is very similar to that of "hourly" teachers from private institutions.

Besides the initial problem, which is the constitution of a stronger bond between the teacher and the course, the discontinuities generated by the fragility of the teaching bonds make the offered courses have difficulties in structuring themselves solidly within the institutions because they always depend on CAPES external financing to move. As an example, we can mention the prolonged absence of funding for new classes offered by the OUB system, which occurred between 2014 and 2017.

Therefore, even though INEP's quality concepts demonstrate reasonably positive outcomes for distance learning courses, further analysis will show that the courses do not have teachers who are effectively linked, but under temporary contracts that expire with the end of the scholarships defined by the program.

This issue brings us to the weaknesses found concerning the internal regulations of IPES on distance education, which end up constituting significant gaps and difficulties of institutional implementation of the modality.

As stated earlier, the OUB program, although considered as such, became so pervaded in the distance education policies of public institutions that it became the synonym for distance education in these institutions, as could be observed in the discussions that took place in the forums. OUB coordinators, especially in the last five years.

The emerging problem has become the broadening of actions aimed at enforcing policies dictated by external funding regulations, such as scholarship payment decrees, OUB student cost parameters, and specific funding notices, such as software recently published by OUB. CAPES.

Overall, these initiatives have weakened the general inducements about distance education within the IPES and MEC, which aim to consolidate distance education as a state policy and not an emergency program. As a result, it was observed in most institutions participating in the OUB system the lack or very fragile existence of strategies that resize distance education as a modality and build parameters of comparison and recognition with the present pattern.

One of the most raised aspects of the recognition of DE in IPES is the constitution of a definite duration time for the distance disciplines, which allows its equivalence to the face-to-face subjects. The apparent lack of parameters is built on a fragile argumentation that the physical absence of the teacher in the classroom does not create conditions to compare the work of both professionals. 
The misunderstanding of the argument lies in the disregard of the typical pedagogical times and movements of Distance Education. If, on the one hand, the teacher is not present on certain days of the week to teach the classes, on the other, he becomes a ubiquitous subject and deconstructs the possible barriers between when he starts educating and when he finishes, due to the characteristic timelessness of teaching work mediated by technologies (Arruda, 2004). Such elements are too obscure and end up directing the teacher to a work dynamics that intensifies more than the work in classroom education because there are no parameters on response times to questions sent in discussion forums by students, or time best suited for promoting and breaking interactions with students. Working time in distance education revokes all other times, such as leisure, family, and other extra virtual spaces, and becomes the conductor of all teaching actions.

Therefore, in a preliminary analysis, it could be stated that the working time in a distance discipline is reasonably higher than the working time in classroom education. It turns out that this premise also has problems, because, as stated earlier, the time for face-to-face learning is well delimited by the time in the classroom and the expected time for the development of related activities. The time in distance education is based on assumptions and predictions about how much time would be devoted to a teaching action that unfolds in countless events and interactions aimed at a mass of students who want and desire a unique, personal accompaniment.

An important aspect to observe is the construction of work parameters that bring distance education closer to the classroom so that these interpretations are reduced.

Understanding that one modality is more "difficult" or complex than another can promote separation between workers and risk of building parameters that distance the graduates of the modality at a distance, hindering their professional recognition in the market.

We believe that the integration between the modalities, with the apparent reduction of what differentiates them and the combination of what brings them together, may constitute the best political path for the strengthening of Distance Education in public institutions of higher education. We have, on the one hand, the fully consolidated face-to-face modality, whose quality parameters have long been forged and, despite possible criticism, we help to build a public higher education that stands out in the quality of private institutions. On the other hand, an incipient modality in the country that needs public support so that it can consolidate itself and be recognized for its quality through the construction of more complete training parameters, involving research and other typical activities of on-site education.

Therefore, the ideal situation for distance education starts from the constitution of internal parameters that equate it to face-to-face education.

This is not about conceptual equality, but about the search for equity. It is political equality that allows both modalities to develop transversal strategies that can deconstruct their borders.

Another element that proves problematic for the constitution of distance education as a modality effectively-recognized in public institutions is related to the documentation that regulates the conditions of entry and permanence of students in these universities.

There are still few face-to-face undergraduate courses from public institutions in Brazil that recognize distance education students to transfer, obtain a new title, exchange, etc. The courses promoted by the OUB system continue to be treated as emergency courses (single offer), and this definition ends up directing the institutions to an interpretation that the rights and duties of the EAD students equivalent to the students of the face-to-face education are not necessary.

Among the losses for students of distance education, we can mention the little investment in institutional monitoring, policies for monitoring students in distance education, possibilities of work opportunities in internships, national and international exchanges, among others.

It is noteworthy that the current legislation (Brazil, 2017) makes it clear that there are no distinctions between classroom and distance education, which is why there is no plausible explanation for such limitations - even the absence of parameters in the graduation standards would not decrease the student's greater right to the equivalence of the course title, regardless of the modality.

Therefore, the maintenance of provisional public distance education programs significantly weakens this modality in public institutions, as they do not allow the establishment of long-term strategies that can bring to the discussion the characteristics and operating conditions of this modality in higher education institutions. educational institutions.

Finally, public distance education in Brazil is in a fragile situation, because it will hardly be included as a regular modality in all areas of knowledge, even in a pandemic context of Covid-19 that forced higher education institutions to incorporate DE technologies and methodologies in their practices. This is because the resistance is still great in universities, as demonstrated by Arruda (2020). 


\section{Conclusions}

We can not make final considerations about Brazilian public DE, but some evidence allows us to analyze and build positions about the place that DE occupies in Brazilian educational policy.

Public distance education, together with private distance education, reinforces the fragility of teacher education, as it is inferred that this is an appropriate modality for this professional profile, mainly due to the decrease in costs.

It turns out that this movement generates other inductions that are, above all, delicate for teacher education policies and for the strengthening of distance education itself. The understanding that eventually builds is that the teacher education, already worn and devalued, remains only the distance education modality, which leads us to understand that it is a modality that further weakens undergraduate degrees.

On the other hand, the distance education modality, when offered in intensity to the undergraduate degrees, is a modality that reinforces possible prejudices against the degree, already weakened by educational public policies, besides strengthening the idea that such a pattern would not be conducive to other higher-level formations with higher defense power of their organized groups (councils, associations, and others).

It is also observed that both MEC and CAPES, by maintaining and reinforcing the policy of extending distance education to initial and continuing teacher education, only restrict the modality to these specific fields and show an academic interpretation that the government Brazilians do not have a consolidated position on this modality and that only imposes it on the less resistant groups-in this case, the teachers.

Few were the regulatory and institutional modifications that could place the DE at a level of at least to be considered equal to the presential education. The lack of effort in this direction has resulted in a significant marginalization of DE in public higher education institutions.

Although we already have ten years of public policies in distance education in Brazil, it is not an exaggeration to say that little progress has been made institutionally in strengthening this modality. We see the opposite-the expansion of movements that, despite legislation, build barriers to distance education, such as restrictions placed on PNAES or the absence of regular funding for public places offered at a distance.

The considerations proposed here point to an unlikely path, which would be a significant change in educational policy that would reconfigure, for educational legislation, the financing of distance education within federal higher education institutions. For these institutions to think of leaving the box imposed by CAPES, that is, to train only teachers in the distance modality.

In this sense, we advocate that the end of the OUB system, despite all the positive points that it represents, especially by placing distance education as a modality offered by IPES, is an ideal condition for other models and other reflections on how distance education will be incorporated in federal higher education institutions can be contemplated.

The future of free distance education probably involves the complete deconstruction of the existing programs in this modality and their replacement by a state policy that includes the indissociability between teaching, research, and extension as the driving force of the public distance modality.

\section{References}

Arruda, E. P., \& Arruda, D. E. P. (2015). Educação à distância no Brasil: políticas públicas e democratização do acesso ao ensino superior. Educação em Revista, 31(3), 321-338.Arruda, E. (2004). Ciberprofessor: novas tecnologias, ensino e trabalho docente. Autêntica Editora. https://doi.org/10.1590/0102-4698117010

Brazil Decree $\mathrm{n}^{0} 9057$ of May 25, 2017. (2017) Regulates art. 80 of the LDB. Retrieved from: http://www.planalto.gov.br/ccivil_03/_Ato2015-2018/2017/Decreto/D9057.htm.

Brazil, Law No. 13,005 of June 25, 2014. (2014, June) Approves the National Education Plan and provides other measures. Retrieved from http://www2.camara.leg.br/legin/fed/lei/2014/lei-13005-25-junho-2014-778970-publicacaooriginal-144468-pl.html

Brazil. Decree 5800 of June 2006, (2006, June) Establishes the Open University of Brazil system. Retrieved from http://www.planalto.gov.br/ccivil_03/_ato2004-2006/2006/decreto/d5800.htm.

Brazil. Decree $\mathrm{n}^{\mathrm{o}} 2494$ of 10 Feb. 1998 (1998, February) Regulates art. 80 of the LDB. Retrieved from http://portal.mec.gov.br/seed/arquivos/pdf/tvescola/leis/D2494.pdf.

Brazil. Decree No. 5622 of December 19, 2005. (2005, December). Regulates art. 80 of the LDB. Retrieved from: http://www.planalto.gov.br/ccivil_03/_ato2004-2006/2005/decreto/d5622.htm.

Brazil. Decree No. 7,234, of July 19, 2010. (2010, July) Provides for the National Student Assistance Program 
(PNAES). Retrieved from https://www.planalto.gov.br/ccivil_03/_ato2007-2010/2010/decreto/d7234.htm.

Brazil. Decree no. 9,057, of May 26, 2017 (2017, April). Federal Official Gazette, Legislative Branch, Brasília.

Capes - Coordination for the Improvement of Higher Education Personnel. (2018) ATUAB. Permanent forum of the coordinators of the OUB system (restrict access). Retrieved from: https://atOUB.capes.gov.br.

Capes. Coordination for the Improvement of Higher Education Personnel. Ordinance No. 03, of January 5, 2017. (2017, January). Creates a working group to institutionalize the OUB with the IPES. Retrieved from: http://www.capes.gov.br/images/stories/download/legislacao/09012017-PORTARIA-N-3-DE-5-DE-JANEIRO-DE -2017.pdf

FERREIRA, Marcello e CLÍMACO, João Carlos Teatine de Souza (2015). Políticas públicas em Educação a Distância: o sistema da Universidade Aberta do Brasil. In: FREITAS, Maria Teresa Menezes, ARRUDA, Eucidio Pimenta e ARAÚJO, Sarah Mendonça de. Na tessitura da distância: entre políticas, docência e tecnologia na EaD. Uberlândia: Edufu.

Formiga, M., \& Litto, F. M. (2009) Distance education: the state of the art. Sao Paulo: Pearson

Hernandes, P. R. (2017). The Open University of Brazil and the democratization of public higher education. Evaluation and Public Policies in Education, 25(95), 283-307. https://doi.org/10.1590/s0104-40362017002500777

Inep - National Institute of Educational Studies and Research Anísio Teixeira (2020). Statistical Synopsis of Higher Education - 2019. Retrieved from:

http://download.inep.gov.br/informacoes_estatisticas/sinopses_estatisticas/sinopses_educacao_basica/sinopse_estat istica_educacao_basica_2019.zip Consulted on 20/05/2021

Inep - National Institute of Educational Studies and Research Anísio Teixeira. (2018) Statistical Synopsis of Basic Education - 2017. Retrieved from

http://download.inep.gov.br/informacoes_estatisticas/sinopses_estatisticas/sinopses_educacao_basica/sinopse_estat istica_educacao_basica_2017.zip. Consulted on 08/01/2020

Kallajian, G. C., \& Aquino, O. F. (2017). Implications of digital technology in teaching: its expression in current scientific literature. In Aquino, Orlando Fernandez and Bordolanza, Ana Maria Esteves. Teaching work and pedagogical training practices: a view of current research. Uberlândia: EDUFU.

Mill, D. R. S. (2016) Strategic management of distance education: constitution, complexities, and challenges. In Neves, Inajara de Salles, Corradi, Wagner, CASTRO, Carmen Lúcia Freitas. Distance Education: Dialogues, shares, practices, and knowledge (pp. 129-144). Barbacena: Eduemg.

National Association of Graduate Studies and Research in Education-ANPED (2017, October). Manifesto of educational entities on the teacher training policy announced by MEC. Retrieved from http://www.anped.org.br/news/manifestacao-das-entidades-educacionais-sobre-politica-de-formacao-de-professore s-anunciada

OECD. Education at a Glance: OECD indicators. OECD Publications (2017). Retrieved from: http://download.inep.gov.br/acoes_internacionais/eag/documentos/2017/relatorio_education_at_a_glance_2017.pdf

Oliveira, C. M. de. (2018). The tutor and tutoring in distance education (EaD): What do tell us dissertations and Brazilian theses in a decade (2005 to 2015) of academic production? Labor \& Education, 27(2), 197-199. https://periodicos.ufmg.br/index.php/trabedu/article/view/9814

Pinto, J. (2014). What explains the lack of teachers in Brazilian schools?. Journal of Educational Policies, 8(15). https://doi.org/10.5380/jpe.v8i15.39189

PNAD, Pesquisa Nacional por Amostra de Domicílios Contínua (2020). Avaiable in https://www.ibge.gov.br/estatisticas/sociais/populacao/9171-pesquisa-nacional-por-amostra-de-domicilios-continuamensal.html? $=\& \mathrm{t}=\mathrm{o}$-que-e. Access on 20 may 2021

\section{Copyrights}

Copyright for this article is retained by the author(s), with first publication rights granted to the journal.

This is an open-access article distributed under the terms and conditions of the Creative Commons Attribution license which permits unrestricted use, distribution, and reproduction in any medium, provided the original work is properly cited. 